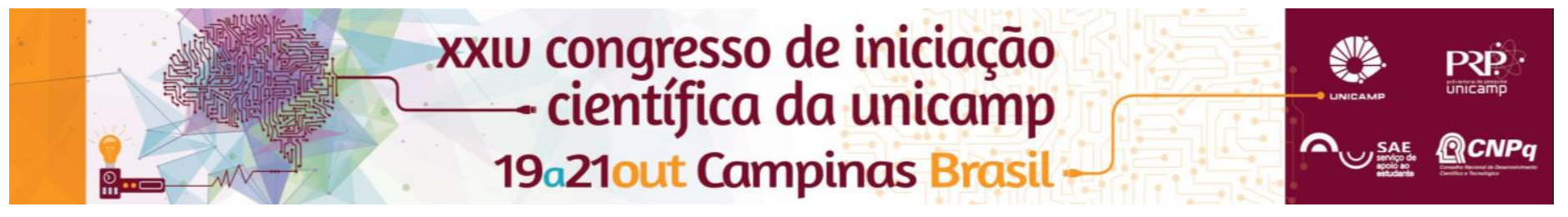

\title{
A Concepção de Currículo no Programa Ensino Integral do Estado de São Paulo.
}

\author{
Larissa Reducino da Silva*, Profa. Dra. Ana Elisa Spaolonzi Queiroz Assis.
}

\begin{abstract}
Resumo
Essa iniciação científica tem como objetivo conhecer a concepção de currículo no Programa Ensino Integral do Estado de São Paulo, tendo como foco as disciplinas eletivas que são componentes fundamentais para a construção do Projeto de Vida dos alunos da educação básica do Ensino Integral. Para tal estudo utilizamos a análise documental e a análise de conteúdo.
\end{abstract}

\section{Palavras-chave \\ Programa Ensino Integral, Educação Integral, Currículo.}

\section{Introdução}

Esta pesquisa de iniciação científica, inserida no projeto "As Experiências Pedagógicas das Políticas de Educação Integral na Amazônia: Rede de Pesquisa e Formação Acadêmica" (UNICAMP - UNIR - UFOPA) do Programa Nacional de Cooperação Acadêmica (PROCAD/CAPES), teve como objetivo conhecer a concepção de currículo no Programa de Ensino Integral do Estado de São Paulo com o propósito de contribuir com as discussões sobre educação integral. Instituído pelo Decreto nํ 57.571, de 2 de dezembro de 2011, pela Secretaria de Educação do estado de São Paulo, o Programa Educação Compromisso de São Paulo teve como um dos seus pilares a proposta de lançar bases para um novo modelo de escola e para um regime mais atrativo do magistério. Nesse contexto surgiu o Programa de Ensino Integral, instituído pela Lei Complementar $\mathrm{n}^{-}$1.164, de 4 de janeiro de 2012 e alterada pela Lei Complementar $\mathrm{n}^{\circ}$ 1.191, de 28 de dezembro de 2012. O Programa de Ensino Integral teve início em 2012 em escolas de Ensino Médio e em 2013 houve uma expansão para os anos finais das escolas de Ensino Fundamental. Nesta perspectiva a pesquisa busca analisar as Diretrizes do Programa de Ensino Integral tendo como referência as teorias críticas e pós-críticas de currículo que, em contraste com as teorias tradicionais, argumenta nenhuma teoria ser neutra implicando, inevitavelmente, em relações de poder. As perspectivas pósestruturalistas já apontavam que as teorias do currículo, ao buscarem definir o que o currículo deveria ser, já estavam envolvidas em questões de poder, pois selecionar e privilegiar um tipo de conhecimento é uma operação de poder (SILVA, 2015).

\section{Resultados e Discussão}

No que diz respeito ao delineamento da pesquisa, o estudo teve como procedimento metodológico a análise de conteúdo das Diretrizes do Programa de Ensino Integral do Estado de São Paulo, disponibilizada pela Secretaria de Educação do Estado de São Paulo. A Lei de Diretrizes e Bases da Educação Nacional - Lei no 9.394/96 - em seu artigo 26 dispõe sobre os currículos da educação básica, colocando que estes devem ser pensados respeitando a base comum e sendo complementados por uma parte diversificada exigida pelas especificidades regionais, culturais e econômicas da sociedade e da vida dos educandos. Com este desígnio o documento oficial das Diretrizes do Programa Ensino Integral do Estado de São
Paulo coloca que para o jovem ser inserido no mundo moderno ele precisa de habilidades complexas e de autonomia pessoal. Há o pressuposto de que os jovens terminam a Educação Básica sem perspectivas pessoais e/ou profissionais para darem continuidade aos estudos e assim garantir a escolha de uma carreira. Desta forma, dentro do Programa existe o Projeto de Vida, cujo objetivo é auxiliar os jovens nessas escolhas, garantindo a realização dos seus sonhos pessoais. Tal Projeto deve ser "construído a partir do provimento da excelência acadêmica, da formação para valores e da formação para o mundo do trabalho" (SÃO PAULO, 2014, p. 15), exigindo um planejamento que define objetivos para serem alçados na vida. Para que o Projeto de Vida seja amplamente trabalhado, dentro do currículo do Ensino Integral as disciplinas eletivas são componentes que ocupam uma posição central para garantir a diversificação das experiências escolares permitindo ampliação e diversificação dos conteúdos.

\section{Conclusões}

Numa análise preliminar, podemos destacar que o Programa Ensino Integral criou novas possibilidades para a construção de um currículo interdisciplinar ao dar espaço para as disciplinas eletivas que compõem o Projeto de Vida dos educandos. Todavia, apesar da ampliação e diversificação do currículo é importante que na continuidade do processo de análise, seja apurada a concepção que acompanha esse novo Ensino Integral, tendo como pressuposto a ênfase na formação que atenda as exigências do mercado de trabalho que o estado de São Paulo tem adotado nos últimos anos como pressuposto para a educação de nível médio.

\section{Agradecimentos}

À Coordenação de Aperfeiçoamento de Pessoal de Nível Superior (CAPES) pelo auxílio; Aos colegas do Procad (UNICAMP - UNIR - UFOPA) pelas experiências compartilhadas; À equipe do Procad - UNICAMP pelas orientações.

\footnotetext{
${ }^{1}$ BRASIL. Lei nº 9.394/1996 Lei de Diretrizes e Bases da Educação Nacional Disponível em: <http://www.planalto.gov.br/ccivil_03/leis/19394.htm> Acesso em: 13 julho de 2016.

2 Secretaria da Educação (2014). Diretrizes do Programa Ensino Integral. São Paulo. Imprensa Oficial, SE

3 SILVA, Tomaz Tadeu da. Documentos de identidade: uma introdução as teorias do currículo. 3. Ed. Belo Horizonte, MG: Autêntica, 2015. 154 p.
} 